\title{
PENGARUH STRATEGI PEMBELAJARAN DISCOVERY DENGAN EKSPOSITORI DAN GAYA BERPIKIR TERHADAP HASIL BELAJAR MATEMATIKA
}

\author{
Bazihaogo Hondro \\ Pengawas Dinas Pendidikan Provinsi Sumatera Utara \\ bazihaogohondro1962@gmail.com
}

\begin{abstract}
Abstrak: Penelitian ini bertujuan untuk mengetahui: (1) perbedaan hasil belajar Matematika antara siswa yang dibelajarkan dengan menggunakan Strategi Discovery dan Strategi Ekspositori, (2) mengetahui perbedaan hasil belajar siswa yang memiliki Gaya Berpikir Divergen dan Gaya Berpikir Konvergen (3) interaksi antara penggunaan Strategi pembelajaran dan Gaya Berpikir dalam mempengaruhi hasil belajar Matematika siswa. Populasi penelitian ini adalah siswa kelas XI SMK Negeri 2 Gunung Sitoli. Teknik penarikan sampel dengan cluster random sampling. Hasil penelitian diperoleh: (1) hasil belajar Matematika siswa yang dibelajarkan dengan menggunakan Strategi Pembelajaran Discovery lebih tinggi dibandingkan dengan hasil belajar Matematika siswa yang dibelajarkan dengan menggunakan Strategi Ekspositori, (2) hasil belajar Matematika siswa yang memiliki Gaya Berpikir Divergen lebih tinggi dibandingkan dengan siswa yang memiliki Gaya Berpikir Konvergen, dan (3) terdapat interaksi antara penggunaan Strategi pembelajaran dengan Gaya Berpikir dalam mempengaruhi hasil belajar Matematika. Dari hasil uji Scheffe diperoleh (1) Rata-rata hasil belajar Matematika siswa yang dibelajarkan dengan Strategi Pembelajaran Discovery berdasarkan Gaya Berpikir Divergen lebih tinggi dibandingkan dengan rata-rata hasil belajar Matematika siswa yang dibelajarkan dengan Strategi Pembelajaran Ekspositori, (2) Rata-rata hasil belajar Matematika siswa dengan Strategi Pembelajaran Ekspositori berdasarkan Gaya Berpikir Konvergen lebih tinggi dibandingkan dengan rata-rata hasil belajar Matematika siswa dengan Strategi Pembelajaran Discovery.
\end{abstract}

Kata Kunci: strategi pembelajaran, diiiscovery learning, ekspositori, gaya berfikir, matematika

\begin{abstract}
This study aims to find out: (1) differences in mathematics learning outcomes between students who are taught using the Discovery Strategy and Expository Strategy, (2) find out the differences in learning outcomes of students who have Divergent Thinking Styles and Convergent Thinking Styles (3) interactions between uses Learning strategies and Thinking Styles in influencing student learning outcomes in Mathematics. The population of this research is the XI grade students of Vocational School 2 Gunung Sitoli. The sampling technique is cluster random sampling. The results were obtained: (1) students 'Mathematics learning outcomes taught using Discovery Learning Strategies were higher than students' Mathematics learning outcomes who were taught using Expository Strategies, (2) Mathematics learning outcomes of students who had higher Divergent Thinking Styles compared to students who have Convergent Thinking Styles, and (3) there is an interaction between the use of learning strategies with Thinking Styles in influencing Mathematics learning outcomes. From the Scheffe test results obtained (1) Average Mathematics learning outcomes of students who are taught with Discovery Learning Strategies based on Divergent Thinking Styles are higher than the average Mathematics learning outcomes of students who are taught with Expository Learning Strategies, (2) Average results Mathematics learning of students with Expository Learning Strategies based on Convergent Thinking Styles is higher than the average student learning outcomes of Mathematics with Discovery Learning Strategies.
\end{abstract}

Keywords: learning strategies, diiiscovery learning, expository, thinking style, mathematics

\section{PENDAHULUAN}

Matematika memegang peranan penting di dalam dunia pendidikan dan juga diperlukan oleh semua ilmu pengetahuan, oleh sebab itu matematika harus dipelajari dan dikuasai oleh setiap peserta didik dengan harapan agar siswa dapat mencapai hasil belajar yang lebih baik. Namun kenyataannya tidak semua siswa dapat mencapai hasil belajar seperti yang diharapkan. Hasil belajar yang dicapai dapat diketahui bila diadakan pengukuran dari pengetahuan siswa. Untuk mengukur sampai dimana tingkat pengetahuan seseorang, harus ada alat pengukuran tertentu yang fungsinya adalah mengukur hasil belajar.

Rendahnya nilai matematika siswa kelas XI SMK Negeri 2 Gunung Sitoli merupakan masalah yang dihadapi dewasa ini, 
dimana keberhasilan siswa dalam mengikuti suatu pelajaran dapat dilihat dari hasil yang diperolehnya. Demikian juga yang terjadi di SMK Negeri 2 Gunung Sitoli. Hal ini menunjukkan bahwa rendahnya kemampuan matematika yang menyebabkan hasil belajar siswa pada bidang studi ini belum sesuai dengan yang diharapkan.

Banyak faktor yang menyebabkan rendahnya hasil belajar matematika siswa kelas XI SMK Negeri 2 Gunung Sitoli, faktor tersebut mungkin datangnya dari dalam diri siswa (faktor internal) dan juga berasal dari faktor luar diri siswa (eksternal), yang berupa faktor internal adalah : motivasi belajar, minat, bakat, intelegensi, cara belajar, gaya berpikir, sedangkan yang berupa faktor eksternal adalah: lingkungan keluarga dan lingkungan sekolah yang berupa metode pembelajaran, media yang digunakan dalam pembelajaran yang tidak sesuai dengan materi atau strategi pembelajaran yang digunakan tidak sesuai dengan karakteristik siswa dan faktor lain yang turut membentuk sehingga terjadi rendahnya prestasi belajar siswa.

Strategi pembelajaran discovery dan ekspositori sebagai salah satu alternatif pembelajaran yang efektif, inovatif dan menyenangkan untuk mata pelajaran matematika, karena strategi pembelajaran discovery adalah suatu strategi pembelajaran yang mengatur pembelajaran sedemikian rupa sehingga siswa memperoleh pengetahuan yang belum diketahuinya tidak melalui pemberitahuan tetapi pengetahuan yang diperoleh melalui penemuan siswa. Konsep belajar ini juga akan mendorong siswa membuat hubungan antara pengetahuan yang dimilikinya dengan penerapannya dalam menghadapi persoalan belajarnya. Konsep belajar ini mempunyai landasan filosofi konstruktivisme, yakni pemahaman berkembang sebagai suatu proses informasi dan mengkonstruksi ide-ide secara mental, sehingga anak akan menemukan sendiri apa yang dipelajarinya, bukan mengetahuinya dari orang lain. Dengan demikian siswa dapat menjelaskan atau menyampaikan ide-ide atau konsep-konsep matematika, disamping negosiasi respon antar siswa akan dapat terjadi dalam proses pembelajaran. Pada akhirnya dapat membawa siswa pada pemahaman yang lebih mendalam tentang konsep matematika yang telah dipelajari. Untuk itu pembelajaran di sekolah hendaknya dimulai dengan pengenalan masalah yang sesuai dengan situasi lingkungan siswa (contextual problem). Dengan mengajukan masalah-masalah kontektual siswa bertahap dibimbing untuk menguasai konsep-konsep matematika. Hal ini sesuai dengan aspek yang diukur dalam mata pelajaran matematika yaitu (1) pemahaman konsep, (2) penalaran dan komunikasi, dan (3) pemecahan masalah. Pengetahuan siswa yang diperoleh dapat bertahan lebih lama dalam ingatan, meningkatkan penalaran siswa, karena mereka harus menganalisis untuk memecahkan masalah, membangkitkan keingintahuan siswa, serta membawa siswa belajar dalam suasana yang lebih menyenangkan.

Dalam pembelajaran matematika, sering kali ditemukan proses berpikir dan cara siswa berbeda dengan strategi guru. Bila hal ini terjadi dan guru memaksakan strateginya, maka akan menghambat aktivitas siswa untuk mengkonstruksikan sendiri pengetahuan yang dimilikinya dalam belajar matematika. Dengan demikian, pembelajaran matematika diharapkan lebih bermakna bagi siswa, karena proses pembelajaran berlangsung alamiah dalam bentuk kegiatan siswa, adalah bekerja dan mengalami, bukan transfer pengetahuan dari guru ke siswa. Hal ini sejalan dengan pendapat Barcheid and Struve (dalam Ratumanan, 2000) yang menyatakan bahwa konsep-konsep teoretis tidak cukup dengan hanya memfokuskan pada individu, justru sesungguhnya siswa yang akan menemukan konsep-konsep, tetapi perlu adanya social impulses, arahan dan bimbingan dari guru di sekolah agar siswa dapat mengkontruksikan konsep-konsep yang diinginkan guna memperoleh ilmu pengetahuan, informasi dan keterampilan yang bermanfaat bagi kepentingan belajarnya.

\section{Hakikat Hasil Belajar Matematika.}

Hasil belajar merupakan hasil dari proses pembelajaran, menurut Dimyati dan Mujiono (2000) hasil belajar yang diperoleh siswa merupakan segala sesuatu yang menunjukkan hasil kemampuan siswa dalam mengerjakan sesuatu dalam bidang pengetahuan, keterampilan dan sikap. Hal ini sama seperti yang dikemukakan oleh Arikunto (2009) bahwa hasil belajar adalah hasil yang diperoleh setelah pembelajaran. Hasil belajar menunjukkan tingkat kemampuan yang diperolah siswa dalam mengikuti proses pembelajaran, oleh karena itu hasil belajar merupakan perubahan kemampuan yang 
meliputi kemampuan kognitif, afektif dan psikomotorik. Seperti yang dikemukakan oleh Bloom ( dalam Winkel 2010) yang dikenal dengan taksonomi Bloom tentang tujuan instruksional yang meliputi tiga ranah yaitu kognitif, afektif dan psikomotorik.

Gàgne \& Briggs (1979) mengemukakan bahwa hasil belajar dapat dikelompokkan ke dalam lima katagori yaitu berupa keterampilanketerampilan intelektual yang memungkinkan kita berinteraksi dengan lingkungan melalui penggunaan simbol-simbol atau gagasangagasan, strategi-strategi kognitif yang merupakan proses-proses kontrol dan dikelompokkan sesuai dengan fungsinya meliputi strategi menghafal, strategi elaborasi, strategi pengaturan, strategi metakognitif, dan strategi afektif. Hasil-hasil belajar yang lain ialah informasi verbal, sikap, keterampilanketerampilan motorik dan tiga dari lima katagori yaitu : keterampilan intelektual, strategi kognitif dan kemampuan verbal yang disejajarkan dengan ranah kognitif Bloom yaitu : pengetahuan (C1), pemahaman (C2), penerapan (C3), analisis (C4), Sintesis (C5), dan evaluasi (C6).

Depdiknas (2004) memberikan ciri matematika adalah penalaran deduktif, yaitu kebenaran suatu konsep atau pernyataan diperoleh sebagai akibat logis dari kebenaran sebelumnya, sehingga kaitan antar konsep atau pernyataan dalam matematika bersifat konsisten. Menurut Hudoyo (1998) matematika adalah sebagai ilmu mengenai struktur dan hubungannya, simbol-simbol diperlukan. Simbol-simbol itu penting untuk membantu aturan dengan operasi yang ditetapkan. Simbolisasi menjamin adanya komunikasi dan mampu memberikan keterangan untuk membentuk suatu konsep baru. Konsep baru terbentuk karena adanya pemahaman terhadap konsep sebelumnya sehingga matematika itu konsepnya tersusun secara hirarkis. Simbolisasi baru akan berarti bila suatu simbol itu dilandasi suatu ide, jadi kita harus memahami ide yang terkandung didalamnya. Dengan perkataan lain ide itu harus dipahami terlebih dahulu sebelum ide itu disimbolkan.

\section{Hakikat Strategi Pembelajaran Discovery}

Strategi pembelajaran discovery adalah suatu strategi pembelajaran yang mengatur pembelajaran sedemikian rupa sehingga siswa memperoleh pengetahuan yang belum diketahuinya tidak melalui pemberitahuan tetapi pengetahuan yang diperoleh melalui penemuan. Hamalik (1993) menyatakan pembelajaran discovery adalah prosedur pembelajaran yang menitik beratkan studi individu, manipulasi objek-objek dan eksperimen yang dilaksanakan siswa sebelum mengambil keputusan.

Pengetahuan yang diperoleh siswa dapat bertahan lebih lama dalam ingatan, meningkatkan penalaran siswa, karena mereka harus menganalisis untuk memecahkan masalah serta membangkitkan keingintahuan siswa. Jika diperhatikan guru sering tidak memberikan cukup waktu pada siswa untuk berpikir dalam hubungannya dengan proses pembelajaran dimana siswa membutuhkan waktu dalam menggunakan daya otaknya untuk berpikir dan memperoleh pengertian tentang prinsip, teknik dan konsep dalam memecahkan suatu masalah.

Pembelajaran penemuan sangat berhubungan dengan pembentukan yang dilakukan oleh siswa secara individu berdasarkan pengalaman-pengalaman langsung pada mereka. Keberhasilan pembelajaran penemuan yang telah dipaparkan di atas sangat tergantung pada tahap pendahuluan, tujuan umum discovery bukan pada terselesainya masalah namun terletak pada pengembangan kemampuan intelektual siswa dan keahliannya dalam bertanya dan mencari jawaban dari pertanyaan tersebut. Santrock (2010 : 447) menekankan bahwa anak harus membangun sendiri pengetahuan dan pemahaman mereka pada pengajaran konstruktivis. Pada masingmasing langkah dalam pembelajaran, mereka harus menginterpretasikan pengetahuan baru mereka dalam konteks apa-apa yang telah mereka pahami.

Menurut Bruner (1968) proses belajar akan berjalan dengan baik dan kreatif jika guru memberikan kesempatan kepada siswa untuk menemukan suatu konsep, teori, aturan, atau pemahaman melalui contoh-contoh yang ia jumpai dalam kehidupannya karena perkembangan kognitif siswa dapat ditingkatkan dengan jalan mengatur bahan atau materi yang akan dipelajari dan menyajikannya sesuai dengan tingkat perkembangannya. Bruner juga menyatakan bahwa perkembangan kognitif siswa terjadi melalui tiga tahap yang ditentukan oleh caranya melihat lingkungan, yaitu: (1) Tahap enaktif, dimana individu melakukan aktivitas-aktivitas dalam usahanya memahami lingkungan, (2) tahap ikonik, dimana individu memahami objek-objek atau dunianya melalui gambar-gambar dan 
visualisasi verbal, (3) tahap simbolik, dimana individu mampu memiliki gagasan-gagasan abstrak atau ide-ide yang dipengaruhi oleh bahasa dan logika.

Pada strategi discovery, keterampilan mental yang dituntut lebih tinggi antara lain: merancang dan melakukan percobaan, mengumpulkan dan menganalisis data dan mengambil kesimpulan. Kemampuan berpikir discovery pada diri siswa hanya dapat berkembang apabila siswa terlibat dalam kegiatan-kegiatan yang menuntut pelaksanaan tugas-tugas mental tersebut. Hal ini sejalan dengan yang dikemukakan oleh Roestiyah (2001) bahwa strategi discovery adalah metode mengajar yang mempergunakan teknik penemuan. Dalam teknik ini siswa dibiarkan menemukan sendiri atau mengalami proses mental itu sendiri. Proses mental tersebut misalnya mengamati, menggolongkan, membuat dugaan, menjelaskan, mengukur, membuat kesimpulan, dan sebagainya.

\section{Hakikat Strategi Pembalajaran Ekspositori}

Pembelajaran secara ekspositori lebih sering dilakukan oleh guru karena sangat sederhana. Strategi pembelajaran ekspositori adalah strategi pembelajaran yang menekankan kepada proses penyampaian materi secara verbal dari seorang guru kepada sekelompok siswa dengan maksud agar siswa dapat menguasai materi pelajaran secara optimal. Tetapi pada strategi pembelajaran ekspositori dominasi guru banyak berkurang karena tidak terus menerus ia berbicara pada awal pelajaran menerangkan materi dan contoh soal, dan pada waktu-waktu yang diperlukan saja. Roy Killen (dalam Sanjaya,2008) menamakan strategi ekspositori ini dengan istilah strategi pembelajaran langsung (direct instruction). Karena dalam strategi ini materi pelajaran disampaikan langsung oleh guru, siswa tidak dituntut untuk menemukan materi itu. Guru menyampaikan informasi materi pelajaran dalam bentuk penjelasan dan penuturan secara lisan yang dikenal dengan istilah ceramah dan siswa dipandang sebagai objek yang menerima apa yang diberikan guru.

Menurut Sanjaya (2008) ciri pembelajaran ekspositori adalah pembelajaran yang menekankan kepada proses dan pusat pembelajaran adalah guru, siswa hanya mendengar dan mencatat seperlunya, komunikasi terjadi satu arah dan menyamaratakan kemampuan akademik siswa.
Strategi pembelajaran ekspositori umumnya berorientasi pada kegiatan yang berpusat kepada tenaga pengajar (teacher oriented), sedangkan siswa bersifat pasif karena hanya mendengar ceramah dari guru tentang materi yang di sampaikan.

Menurut Hamid (2009) Teori behavioristik seringkali tidak mampu menjelaskan situasi belajar yang kompleks, sebab banyak variabel atau hal-hal yang berkaitan dengan pendidikan dan/atau belajar yang dapat diubah menjadi sekedar hubungan stimulus dan respon. Teori ini tidak mampu menjelaskan penyimpangan-penyimpangan yang terjadi dalam hubungan stimulus dan respon.

\section{Gaya Berpikir Divergen}

Berpikir divergen merupakan proses kognitif yang memerlukan individu membangkitkan berbagai solusi yang berbeda untuk menyelesaikan suatu masalah, selanjutnya Gulo (2002) menyatakan bahwa berpikir divergen bertitik tolak dari suatu peristiwa menuju ke berbagai kemungkinan, selanjutnya Sloane (2011) menyatakan bahwa berpikir divergen membuat kita melangkah menjauhi topik utama masalah ke berbagai arah, artinya ketika seseorang berpikir divergen ia akan mampu melahirkan berbagai macam gagasan yang tidak berhubungan dengan permasalahan awal atau konsep yang sedang diperbincangkan, ia akan berpikir dan berimajinasi sehingga akan menghasilkan begitu banyak solusi atas suatu permasalahan

Einstein (dalam Sloane, 2011) mengatakan bahwa imajinasi adalah lebih penting ketimbang pengetahuan. Berpikir divergen memungkinkan seseorang menggunakan imajinasi dalam mengeksplorasi berbagai kemungkinan-kemungkinan baru yang mencakup pertimbangan terhadap seluruh sudut pandang yang tidak konvensional namun dapat menghasilkan banyak gagasan-gagasan yang cemerlang yang dapat memberi suatu penyelesaian terhadap masalah yang dihadapi.

Munandar (1992) menjelaskan bahwa gaya berpikir divergen adalah gaya berpikir kreatif, yang merupakan kemampuan berpikir untuk memberikan berbagai kemungkinan jawaban berdasarkan informasi atau data yang diberikan dengan penekanan pada kuantitas, ketepatgunaan, dan beragam jawaban yang lebih bebas dan terbuka. Selanjutnya Munandar juga menyatakan, bahwa berpikir divergen 
memiliki empat ciri utama, yaitu: (1) kelancaran; (2) kelenturan; (3) keaslian; dan (4) perluasan. Menurut Noe dalam sihombing (2009) karakteristik orang yang memiliki gaya berpikir divergen yaitu: (1) sangat baik untuk memunculkan gagasan-gagasan; (2) melihat obyek permasalahan dari berbagai perspektif yang memberi makna dan nilai; (3) tertarik pada obyek orang, budaya dan seni. Dalam implikasi pembelajaran matematika, harus mampu menyelesaikan masalah dari berbagai cara dan pengaturan situasi belajar yang mendorong siswa untuk memberikan ragam cara penyelesaian masalah, cara berpikir divergen sesuai dengan cara-cara untuk mengetahui yang bersifat non-verbal seperti perasaan dan emosi, kesadaran yang berkenaan dengan perasaan, kesadaran spasial, mengenal bentuk dan pola, musik, seni kepekaan warna, melakukan pendekatan coba-coba, intuitif, holistik memahami konsep, kratifitas dan visualisasi

\section{Gaya Berpikir Konvergen}

Berpikir konvergen merupakan gaya berpikir normal yang biasa kita pakai, ketika mendengar sebuah masukan, naluri memerintahkan untuk menelaahnya, mengkritiknya dan menganalisis konsekwensikonsekwensinya dengan penekanan khusus pada kemungkinan adanya kesalahan dari masukan tersebut, hal ini sejalan seperti yang dikemukakan oleh Sloane (2011) bahwa seseorang yang berpikir konvergen akan memusatkan perhatian secara mendalam pada satu sasaran dan mempersempit pilihan-pilihan kita untuk memperoleh solusi yang diinginkan.

Berpikir konvergen merupakan gaya berpikir yang menuju ke satu arah, untuk memberikan jawaban atau penarikan kesimpulan yang logis dari informasi yang diberikan dengan penekanan pada pencapaian jawaban tunggal yang paling tepat. Berpikir konvergen berkaitan dengan berpikir logis, sistematis, linier, berurutan, analistis, objektif, harfiah, terstruktur dapat diramalkan. Kagan dan lang (dalam Sihombing, 2009) menjelaskan bahwa seseorang yang berpikir konvergen beranjak dari banyak informasi, dan selanjutnya informasi tersebut diidentifikasi dari aspek prinsip, konsep atau kategori, kemudian disimpulkan satu jawaban yang benar.

Guilford (dalam Ansori, 2007) menyatakan bahwa cara berpikir konvergen adalah cara-cara individu dalam memikirkan sesuatu dengan berpandangan bahwa hanya ada satu jawaban yang benar dengan menggunakan pengetahuan yang kita miliki guna menelaah konsep-konsep dan melihat kegunaan konsep. Selanjutnya, gaya berpikir konvergen dapat disejajarkan dengan gaya berpikir vertikal, yang berpikir sistematis dan terfokus, serta cenderung untuk mengelaborasi atau meningkatkan pengetahuan yang ada. Cara berpikir konvergen akan membuat kita menggunakan pengetahuan yang kita miliki guna menelaah konsep-konsep dan melihat di tempat mana konsep-konsep tersebut akan digunakan.

Perbedaan berpikir divergen dan konvergen dalam menyelesaikan suatu problem secara tegas dinyatakan oleh Seifert (dalam Sihombing, 2009) bahwa berbagai situasi dan masalah mendorong siswa untuk menyelesaikan masalah tersebut dengan menggunakan gaya berpikir divergen. Di pihak lain, terdapat kecenderungan bahwa seorang siswa selalu menggunakan salah satu gaya berpikir dalam menyelesaikan masalah. Kecenderungan dalam menggunakan salah satu gaya berpikir sangat dipengaruhi oleh pengalaman belajar yang diperoleh oleh masing-masing siswa dalam mengikuti proses pembelajaran di sekolah.

Rumusan penelitian ini adalah: (1) Apakah hasil belajar matematika siswa kelas XI SMK Negeri 2 Gunung Sitoli yang diajar dengan strategi pembelajaran discovery lebih tinggi dengan hasil belajar matematika siswa yang diajar dengan strategi pembelajaran ekspositori; (2) Apakah hasil belajar matematika siswa kelas XI SMK Negeri 2 Gunung Sitoli yang memiliki gaya berpikir divergen lebih tinggi dari hasil belajar matematika siswa yang memiliki gaya berpikir konvergen; dan (3) Apakah terdapat pengaruh interaksi antara strategi pembelajaran dengan gaya berpikir terhadap hasil belajar matematika siswa kelas XI SMK Negeri 2 Gunung Sitoli?

\section{METODE}

Penelitian ini dilaksanakan di SMK Negeri 2 Gunung Sitoli. Teknik pengambilan sampel dilakukan dengan teknik cluster random sampling, selanjutnya melalui pengundian kelas XI sebagai kelas yang diberi perlakuan dengan strategi pembelajaran discovery (kelas eksprimen) terpilih sebagai kelas dengan strategi pembelajaran ekspositori (kelas kontrol). Sebelum dilakukan eksperimen, kedua kelas sampel terlebih dahulu diberi tes 
untuk mengetahui gaya berfikir siswa. Gaya belajar dikategorikan atas gaya belajar divergen dan konvergen.

Penelitian ini menggunakan metode eksperimen dengan rancangan quasi eksperimen desain faktorial $2 \times 2$. Melalui desain ini akan dibandingkan pengaruh strategi pembelajaran discovery dan strategi pembelajaran ekspositori. Strategi pembelajaran discovery dan strategi pembelajaran ekspositori diperlakukan kepada kelompok eksperimen siswa ditinjau dari gaya berpikir yang berbeda. Gaya berpikir dibedakan atas gaya berpikir divergen dan gaya berpikir konvergen. Strategi pembelajaran sebagai variabel bebas, gaya berpikir sebagai variabel moderator dan hasil belajar matematika sebagai variabel terikat. Variabel-variabel tersebut selanjutnya akan ditinjau dalam penelitian dengan desain sebagai berikut:

Tabel 1. Desain Faktorial $2 \times 2$

\begin{tabular}{|c|c|c|}
\hline \multirow{2}{*}{ Gaya Berfikir $(\mathrm{B})$} & \multicolumn{2}{|c|}{ Strategi Pembelajaran $(\mathrm{A})$} \\
\cline { 2 - 3 } & $\begin{array}{c}\text { Discovery } \\
\left(\mathrm{A}_{1}\right)\end{array}$ & $\begin{array}{c}\text { Ekspositori } \\
\left(\mathrm{A}_{2}\right)\end{array}$ \\
\hline Divergen $\left(\mathrm{B}_{1}\right)$ & $\mathrm{A}_{1} \mathrm{~B}_{1}$ & $\mathrm{~A}_{2} \mathrm{~B}_{1}$ \\
\hline Konvergen $\left(\mathrm{B}_{2}\right)$ & $\mathrm{A}_{1} \mathrm{~B}_{2}$ & $\mathrm{~A}_{2} \mathrm{~B}_{2}$ \\
\hline
\end{tabular}

Keterangan :

A : Strategi pembelajaran

A1 : Strategi pembelajaran Discovery

A2 : Strategi pembelajaran Ekspositori

B1 : Gaya berpikir divergen

B2 : Gaya berpikir konvergen

A1B1 : Hasil belajar Matematika siswa yang yang diajar dengan strategi pembelajaran Discovery yang memiliki gaya berpikir divergen

A1B2 : Hasil belajar matematika siswa yang diajar dengan strategi pembelajaran Discovery yang memiliki gaya berpikir konvergen

A2B1 : Hasil belajar Matematika siswa yang diajar dengan srtategi pembelajaran Ekspositori yang memiliki gaya berpikir divergen

A2B2 : Hasil belajar matematika siswa yang diajar dengan strategi pembelajaran Ekspositori yang memiliki gaya berpikir konvergen

Teknik Analisis Data

Teknik analisis data yang digunakan adalah Teknik Statistik Deskriptif dan
Inferensial. Teknik statistik deskriptif digunakan untuk mendeskripsikan data, antara lain: nilai rata-rata (mean), median, modus, standard deviasi $(\mathrm{Sd})$ dan kecenderungan data. Teknik statistik Inferensial digunakan untuk menguji hipotesis penelitian, di mana teknik Inferensial yang akan digunakan adalah teknik Analisis Varians dua jalur (disain faktorial 2x2) dengan taraf signifikan 0,05. Sebelum Anava dua jalur dilakukan, terlebih dahulu ditentukan persyaratan analisis yakni persyaratan Normalitas menggunakan Uji Lilliefors, sedangkan untuk uji persyaratan Homogenitas menggunakan Uji Fisher (F) dan Uji Bartlett (Sudjana,1984).

Setelah melakukan pengujian persyaratan analisis, selanjutnya dilakukan pengujian Anava 2 jalur. Karena Anava 2 jalur signifikan, maka diadakan uji lanjut (post hoc test). Uji lanjut dilakukan dengan uji Scheffẻ karena jumlah sampel tiap sel tidak sama (n tidak sama). Selanjutnya, untuk keperluan pengujian hipotesis, dirumuskan hipotesis statistik seperti berikut:

a. Hipotesis pertama :

$$
\begin{array}{ll}
\text { Ho } & : \mu_{A 1} \leq \mu_{A 2} \\
\text { H1 }: \mu_{A 1}>\mu_{A 2}
\end{array}
$$

b. Hipotesis kedua :

$$
\begin{array}{ll}
\text { Ho } & : \mu_{B 1} \leq \mu_{B 2} \\
\text { H1 } & : \mu_{B 1}>\mu_{B 2}
\end{array}
$$

c. Hipotesis ketiga :

Ho : $\mathrm{A} \times \mathrm{B}=0$

$\mathrm{H} 1: \mathrm{A} \times \mathrm{B} \neq 0$

Keterangan :

$\mathrm{A}=$ Strategi pembelajaran

$\mathrm{B}=$ Gaya berpikir

$\mathrm{A}_{1}=$ Strategi pembelajaran discovery

$A_{2}=$ Strategi pembelajaran ekspositori

$\mathrm{B}_{1}=$ Gaya berpikir divergen

$\mathrm{B}_{2}=$ Gaya berpikir konvergen

$\mu_{A 1}=$ Rata-rata basil belajar Matematika siswa yang diajarkan dengan strategi pembelajaran Discovery

$\mu_{A 2}=$ Rata-rata hasil belajar Matematika siswa yang diajarkan dengan strategi pembelajaran Ekspositori

$\mu_{B 1}=$ Rata-rata hasil belajar Matematika siswa yang memiliki gaya berpikir divergen 
$\mu_{B 1}=$ Rata-rata hasil belajar Matematika siswa yang memiliki gaya berpikir konvergen

$\mathrm{A} \times \mathrm{B}=$ Interaksi antara strategi pembelajaran dengan gaya berpikir.

\section{HASIL DAN PEMBAHASAN \\ Hasil}

Pengujian hipotesis dilakukan untuk membuktikan kebenaran hipotesis yang telah ditetapkan sehingga diperoleh data apakah hipotesis yang dirancang dalam sebuah penelitian ditolak atau diterima. Untuk keperluan pengujian hipotesis dengan menggunakan teknik analisis varian dua jalur (ANAVA) faktorial $2 \times 2$ dan kemudian dilanjutkan dengan uji lanjut dengan menggunakan uji Scheffe, diperlukan harga rata-rata tiap kelompok perlukan sebagai sumber data penelitian, berikut ini disajikan rangkuman data hasil belajar matematika siswa sebagai sumber pengolahan data untuk pengujian hipotesis. Rangkuman data tersebut dapat dilihat pada Tabel 1 dengan menggunakan analisis deskriptif.

Tabel 2. Rangkuman Data Hasil Perhitungan Analisis Deskriptif.

\begin{tabular}{|c|c|c|c|c|}
\hline \multirow{2}{*}{\multicolumn{2}{|c|}{$\begin{array}{c}\text { RINGKASAN } \\
\text { DATA }\end{array}$}} & \multicolumn{2}{|c|}{ STRATEGI PEMBELAJARAN } & \multirow{2}{*}{ Total } \\
\hline & & Discovery (Al) & Ekspositori (A2) & \\
\hline \multirow{2}{*}{$\begin{array}{l}\text { Gaya } \\
\text { Bepikir }\end{array}$} & $\begin{array}{l}\text { Diver- } \\
\text { gen (B1) }\end{array}$ & $\begin{array}{c}\mathrm{n}_{1}=24 \\
\sum \mathrm{X}_{1}=762 \\
\sum \mathrm{X}_{1}{ }_{1}=24448 \\
\overline{\mathrm{X}}_{1}=31,75 \\
\mathrm{~s}^{2}{ }_{1}=4,35\end{array}$ & $\begin{array}{c}\mathrm{n}_{3}=19 \\
\sum \mathrm{X}_{3}=501 \\
\sum \mathrm{X}_{3}{ }_{3}=13373 \\
\overline{\mathrm{X}}_{3}=26,39 \\
\mathrm{~S}^{2}{ }_{3}=6,98\end{array}$ & $\begin{aligned} \mathrm{N}_{1,3} & =43 \\
\sum \mathrm{X}_{1,3} & =1263 \\
\sum \mathrm{X}_{1,3}^{2} & =37821 \\
\overline{\mathrm{X}}_{1,3} & =29,07 \\
\mathrm{~s}_{1,3}^{2} & =10,20\end{aligned}$ \\
\hline & $\begin{array}{l}\text { Konver- } \\
\text { gen (B2) }\end{array}$ & $\begin{array}{c}\mathrm{n}_{2}=16 \\
\sum \mathrm{X}_{2}=419 \\
\sum \mathrm{X}^{2}{ }_{2}=11103 \\
\overline{\mathrm{X}}_{2}=26,25 \\
\mathrm{~s}_{2}{ }_{2}=5,98\end{array}$ & $\begin{array}{c}\mathrm{n}_{4}=21 \\
\sum \mathrm{X}_{4}=615 \\
\sum \mathrm{X}_{4}{ }_{4}=18225 \\
\overline{\mathrm{X}}_{4}=29,35 \\
\mathrm{~S}_{4}{ }_{4}=7,38\end{array}$ & $\begin{aligned} \mathrm{N}_{2,4} & =37 \\
\sum \mathrm{X}_{2,4} & =1034 \\
\sum \mathrm{X}_{2,4}^{2} & =29328 \\
\bar{X}_{2,4} & =27,8 \\
\mathrm{~s}_{2,4}^{2} & =8,77\end{aligned}$ \\
\hline \multicolumn{2}{|c|}{ Total } & $\begin{array}{c}\mathrm{N}_{1,2}=40 \\
\sum \mathrm{P}_{1,2}=1181 \\
\sum \mathrm{X}_{1,2}^{2}=35551 \\
\overline{\mathrm{X}}_{1,2}=29 \\
\mathrm{~s}^{2}{ }_{1,2}=13,21\end{array}$ & $\begin{aligned} \mathrm{N}_{3,4} & =40 \\
\sum \mathrm{P}_{3,4} & =1116 \\
\sum \mathrm{X}_{3,4}^{2} & =31598 \\
\overline{\mathrm{X}}_{3,4} & =27,87 \\
\mathrm{~s}^{2}{ }_{3,4} & =7,36\end{aligned}$ & $\begin{array}{c}\mathrm{N}_{\mathrm{g}}=80 \\
\sum \mathrm{X}_{\mathrm{g}}=2297 \\
\sum \mathrm{X}_{\mathrm{g}}=67149 \\
\overline{\mathrm{X}}_{\mathrm{g}}=28,43 \\
\mathrm{~s}_{\mathrm{g}}=10,46\end{array}$ \\
\hline
\end{tabular}

Setelah data tabel 2 diolah dengan ANAVA 2 jalur faktorial 2 × 2, maka diperoleh hasil analisis seperti ditunjukkan pada Tabel 3.

Tabel 3. Ringkasan Perhitungan ANAVA Faktorial 2x2

\begin{tabular}{|l|c|c|c|c|c|c|}
\hline \multicolumn{1}{|c|}{ Sumber Varians } & JK & $\mathbf{d k}$ & $\mathbf{K T}$ & $\mathbf{F}_{\text {hitung }}$ & $\begin{array}{c}\mathbf{F}_{\text {tabel }} \\
(\mathbf{\alpha = 0 , 0 5 )}\end{array}$ & Ket. \\
\hline Strategi Pembelajaran & 52,813 & 1 & 52,813 & 5,269 & & Signifikan \\
Gaya Berpikir & 40,45 & 1 & 40,45 & 4,036 & 3,96 & Signifikan \\
Interaksi & 314,48 & 1 & 314,48 & 34,074 & & Signifikan \\
\cline { 6 - 8 } Antar Kelompok & 434,74 & 3 & 144,91 & & & \\
\hline Dalam kelompok (galat) & 761,64 & 76 & 10,022 & & & \\
\cline { 6 - 8 } Total & 1196,4 & 79 & & & & \\
\hline
\end{tabular}

Berdasarkan perhitungan ANAVA faktorial $2 \times 2$ diperoleh Fhitung $=5,269$ sedangkan nilai Ftabel $=3,96$ untuk dk $(1,76)$ dan taraf nyata $\alpha=0,05$. Ternyata nilai Fhitung $=5,269>$ Ftabel sehingga pengujian hipotesis menolak Ho. Dengan demikian dapat ditarik 
kesimpulan bahwa hasil belajar Matematika siswa yang dibelajarkan dengan Strategi Pembelajaran Discovery lebih tinggi dibanding dengan Strategi Pembelajaran Ekspositori dapat diterima dan terbukti secara empirik. Hal ini juga terlihat dari rata-rata hasil belajar Matematika yang dibelajarkan dengan Strategi Pembelajaran Discovery $(\bar{X}=29)$ lebih tinggi dari hasil belajar Matematika yang dibelajarkan dengan Strategi Pembelajaran Ekspositori $(\bar{X}=$ 27,87).

Berdasarkan perhitungan ANAVA faktorial 2x2 diperoleh Fhitung $=4,036$ sedangkan nilai Ftabel $=3,96$ untuk dk $(1,76)$ dan taraf nyata $\alpha=0,05$. Ternyata nilai Fhitung $=4,036>$ Ftabel sehingga pengujian hipotesis menolak Ho. Dengan demikian dapat ditarik kesimpulan bahwa hasil belajar Matematika siswa yang memiliki Gaya Berpikir Divergen lebih tinggi dibanding siswa yang memiliki Gaya Berpikir Konvergen dapat diterima dan terbukti secara empirik. Hal ini juga terlihat dari rata-rata hasil belajar Matematika yang memiliki Gaya Berpikir Divergen $(\bar{X}=29,07)$ lebih tinggi dari hasil belajar Matematika yang yang memiliki Gaya Berpikir Konvergeni $(\bar{X}=$ 27,8).

Berdasarkan perhitungan ANAVA faktorial $2 \times 2$ diperoleh Fhitung $=34,07$ sedangkan nilai Ftabel $=3,96$ untuk dk $(1,76)$ dan taraf nyata $\alpha=0,05$. Ternyata nilai Fhitung $=34,07>$ Ftabel sehingga pengujian hipotesis menolak Ho. Dengan demikian dapat ditarik kesimpulan bahwa terdapat interaksi antara Strategi Pembelajaran dan Gaya Berpikir dalam meningkatkan hasil belajar Matematika siswa dapat diterima dan terbukti secara empirik.

Untuk mengetahui interaksi antara Strategi Pembelajaran dan Gaya Berpikir terhadap hasil belajar Matematika, maka dilakukan uji lanjut dengan Uji Scheffe. Perhitungan untuk uji Scheffe dapat dilihat pada tabel 4.

Tabel 4. Ringkasan Hasil Pengujian Dengan Menggunakan Uji Scheffe

\begin{tabular}{|c|c|c|c|c|c|}
\hline \multirow{2}{*}{ No } & \multicolumn{2}{|c|}{ Hipotesis Statistik } & \multirow{2}{*}{$F_{\text {hitung }}$} & \multicolumn{2}{c|}{$\mathrm{F}_{\text {tabel }}$} \\
\cline { 5 - 6 } & & & $\alpha=5 \%$ & $\alpha=1 \%$ \\
\hline 1 & Ho: $\mu \mathrm{A} 1 \mathrm{~B} 1=\mu \mathrm{A} 2 \mathrm{~B} 1$ & Ha: $\mu \mathrm{A} 1 \mathrm{~B} 1>\mu \mathrm{A} 2 \mathrm{~B} 1$ & 5,69 & 2,73 & 4,30 \\
\hline 2 & Ho: $\mu \mathrm{A} 1 \mathrm{~B} 1=\mu \mathrm{A} 1 \mathrm{~B} 2$ & Ha: $\mu \mathrm{A} 1 \mathrm{~B} 1>\mu \mathrm{A} 1 \mathrm{~B} 2$ & 5,32 & 2,73 & 4,30 \\
\hline 3 & Ho: $\mu \mathrm{A} 1 \mathrm{~B} 1=\mu \mathrm{A} 2 \mathrm{~B} 2$ & Ha: $\mu \mathrm{A} 1 \mathrm{~B} 1>\mu \mathrm{A} 2 \mathrm{~B} 2$ & 2,75 & 2,73 & 4,30 \\
\hline 4 & Ho: $\mu \mathrm{A} 2 \mathrm{~B} 1=\mu \mathrm{A} 1 \mathrm{~B} 2$ & Ha: $\mu \mathrm{A} 2 \mathrm{~B} 1<\mu \mathrm{A} 1 \mathrm{~B} 2$ & 0,15 & 2,73 & 4,30 \\
\hline 5 & Ho: $\mu \mathrm{A} 2 \mathrm{~B} 1=\mu \mathrm{A} 2 \mathrm{~B} 2$ & Ha: $\mu \mathrm{A} 2 \mathrm{~B} 1>\mu \mathrm{A} 2 \mathrm{~B} 2$ & 2,90 & 2,73 & 4,30 \\
\hline 6 & Ho: $\mu \mathrm{A} 2 \mathrm{~B} 2=\mu \mathrm{A} 1 \mathrm{~B} 2$ & Ha: $\mu \mathrm{A} 2 \mathrm{~B} 2>\mu \mathrm{A} 1 \mathrm{~B} 2$ & 2,80 & 2,73 & 4,30 \\
\hline
\end{tabular}

Berdasarkan Tabel 4. di atas terdapat satu dari enam kombinasi yang dibandingkan menunjukkan hasil yang tidak signifikan, hal ini disebabkan oleh tidak terdapatnya perbedaan yang signifikan antara rata-rata hasil belajar Matematika yang dibelajarkan dengan menggunakan Strategi Pembelajaran Ekspositori berdasarkan Gaya Berpikir Divergen dan rata-rata hasil belajar Matematika yang dibelajarkan dengan Strategi Pembelajaran Discovery berdasarkan Gaya Berpikir Divergen.

Hasil pengujian lanjut di atas, menunjukkan adanya interaksi antara Strategi Pembelajaran dan Gaya Berpikir terhadap hasil belajar Matematika siswa kelas XI SMK Negeri 2 Gunung Sitoli. Interaksi Strategi Pembelajaran dan Gaya Berpikir dapat ditunjukkan seperti pada gambar 1 .

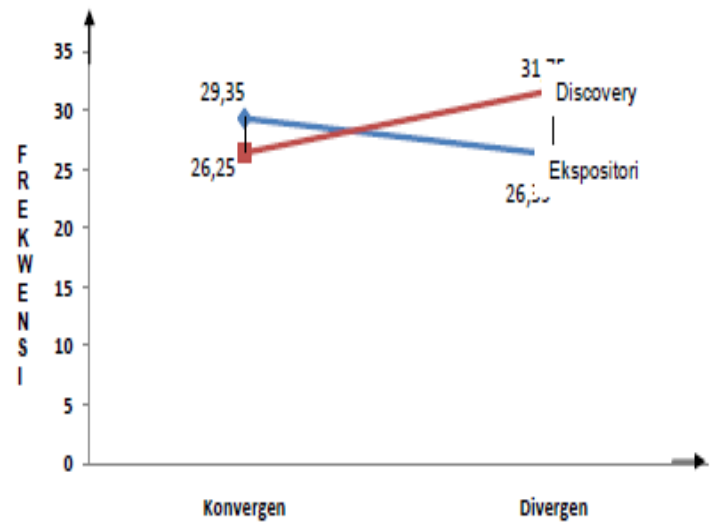

Gambar 1. Interaksi Antara Strategi Pembelajaran Dan Gaya Berpikir

Berdasarkan hasil pengujian hipotesis ketiga yang menyatakan adanya interaksi antara Strategi Pembelajaran dengan Gaya Berpikir maka perlu dilakukan uji perbedaan rata-rata 
antara dua proporsi. Gambar 1 menunjukkan pengaruh dan interaksi dari Strategi Pembelajaran dan Gaya Berpikir terhadap hasil belajar Matematika yang diperoleh siswa, rata rata hasil belajar Matematika yang dibelajarkan dengan Strategi Pembelajaran Discovery lebih tinggi dibandingkan dengan Strategi Pembelajaran Ekspositori. Penelitian ini juga membuktikan faktor Gaya Berpikir sebagai salah satu karakteristik siswa perlu diperhatikan karena terbukti bahwa Gaya Berpikir berpengaruh terhadap hasil belajar Matematika.

\section{Pembahasan Hasil Penelitian}

Dari hasil pengolahan data yang dilakukan terdapat perbedaan hasil belajar matematika antara peserta didik yang diajarkan dengan strategi pembelajaran discovery dan siswa yang diajarkan dengan strategi ekspositori, hal ini ditunjukkan dari nilai ratarata hasil belajar Matematika siswa yang diajar dengan menggunakan strategi pembelajaran discovery lebih tinggi dibandingkan siswa yang diajar dengan menggunakan strategi pembelajaran ekspositori. Kenyataan ini membuktikan bahwa penggunaan strategi pembelajaran discovery baik dalam meningkatkan pengetahuan peserta didik dalam pembelajaran Matematika pada siswa kelas XI SMK Negeri 2 Gunung Sitoli

Suryosubroto (dalam Trianto, 2009) menyatakan bahwa discovery merupakan bagian dari inquiri, atau inquiri merupakan perluasan proses discovery yang digunakan lebih mendalam, dimana strategi ini merupakan rangkaian kegiatan belajar yang melibatkan secara maksimal seluruh kemampuan siswa untuk mencari secara sistematis, kritis, logis, analitis sehingga siswa dapat menyelesaikan masalah dan mampu berpikir kreatif, produktif dan menjadi trampil dalam memperoleh, menganalisis informasi dan pada akhirnya mereka dapat merumuskan sendiri penemuannya dengan penuh percaya diri. Ada tiga sasaran utama kegiatan pembelajaran discovery di kelas, yaitu sebagai berikut: (1) Keterlibatan siswa secara maksimal dalam proses kegiatan belajar; (2) keterarahan kegiatan secara logis dan sistematis pada tujuan pembelajaran; dan (3) mengembangkan sikap percaya diri siswa tentang apa yang ditemukan dalam proses discovery

Selanjutnya Trianto (2009) menyatakan bahwa untuk menciptakan kondisi seperti itu, peranan guru adalah sebagai: (1) Motivator, artinya guru memberi rangsangan agar siswa aktif dan bergairah berpikir,(2) Fasilitator, guru menunjukkan jalan keluar jika siswa mengalami kesulitan, (3) Penanya, guru menyadarkan siswa dari kekeliruan yang mereka buat, (4) Administrator, guru bertanggung jawab terhadap seluruh kegiatan kelas, (5) Pengarah, guru memimpin kegiatan siswa untuk mencapai tujuan yang diharapkan, (6) Manajer, guru mengelola sumber belajar, waktu, dan mengorganisasi kelas, dan (7) Rewarder, guru memberi penghargaan pada prestasi yang dicapai siswa

Ada lima tahap yang harus ditempuh dalam strategi discovery, yaitu (a) perumusan masalah untuk dipecahkan peserta didik, (b) penetapan jawaban sementara atau pengajuan hipotesis, (c) peserta didik mencari informasi, data dan fakta yang diperlukan untuk menjawab atau memecahkan masalah dan menguji hipotesis, (d) menarik kesimpulan dari jawaban atau generalisasi. (e) aplikasi kesimpulan atau generalisasi dalam situasi baru.

Sanjaya (2008: 178) menyatakan strategi pembelajaran ekspositori adalah strategi pembelajaran yang menekankan kepada proses penyampaian materi secara verbal dari seorang guru kepada sekelompok siswa dengan maksud agar siswa dapat menguasai materi pelajaran secara optimal. Strategi pembelajaran ekspositori merupakan bentuk dari pendekatan berorientasi kepada guru (teacher centered approach). Dikatakan demikian karena dalam strategi ini guru memegang peran yang sangat dominan, melalui strategi ini guru menyampaikan materi pelajaran yang disampaikan itu dapat dikuasai siswa dengan baik. Fokus utama strategi ini adalah kemampuan akademik (academik achievement) siswa.

Dari hasil pengamatan dan diskusi peneliti bersama dengan guru dalam pengkajian strategi pembelajaran pada kelas discovery dan ekspositori, untuk kelas perlakuan strategi pembelajaran discovery untuk tahapan perumusan masalah untuk dipecahkan peserta didik, guru hanya memberi masalah atau soalsoal yang berbeda untuk dicari penyelesaiannya oleh siswa sedangkan pada kelas yang diberi perlakuan strategi pembelajaran ekspositori guru lebih banyak menyelesaikan soal-soal yang disajikan dalam contoh. Hal ini dibuktikan dengan lamanya waktu penyajian materi pelajaran pada kelas ekspositori dibandingkan dengan waktu penyajian materi pada kelas 
discovery. Pada kelas discovery siswa menemukan sendiri pengetahuan dari masalah yang diberikan guru sehingga pengetahuan tersebut akan lebih bermakna. Hal ini menyebabkan menjadi penyebab tingginya hasil belajar matematika pada kelas discovery.

Hasil penelitian menunjukkan bahwa rata-rata hasil belajar Matematika siswa yang memiliki gaya berpikir divergen lebih tinggi dari pada hasil belajar Matematika siswa yang memiliki gaya berpikir konvergen. Hal ini mengindikasikan bahwa siswa yang memiliki gaya berpikir divergen lebih mampu memahami pelajaran Matematika dibandingkan dengan siswa yang memiliki gaya berpikir konvergen

Proses kognisi, atau proses berpikir, berkaitan dengan penjelasan mengenai apa yang terjadi dalam otak siswa selama memperoleh pengetahuan baru, yaitu bagaimana pengetahuan baru tersebut diperoleh, diatur, disimpan dalam memori, dan digunakan lebih lanjut dalam pembelajaran dan pemecahan masalah.

Berpikir divergen adalah kemampuan seseorang berpikir untuk memberikan berbagai kemungkinan jawaban berdasarkan informasi atau data yang diberikan. Pada dasarnya orang yang memiliki gaya berpikir divergen akan mampu memecahkan masalah dari berbagai cara, mereka berpikir acak dan lateral, penuh imajinasi, abstrak dan memiliki kreativitas yang tinggi, orisinalitas, daya cipta dan bakat artistik, orang yang berpikir divergen akan lebih santai, kurang terikat oleh parametrik ilmiah dan matematis. Umumnya mereka memiliki potensi yang besar untuk mencapai prestasi yang luar biasa.

Adapun gaya berpikir konvergen adalah kemampuan seseorang berpikir ke satu arah tujuan atau memusat, orang yang memiliki gaya berpikir konvergen memiliki pola pikir yang sistematis, berurutan, analitik, cenderung berpikir menggunakan otak kiri yang menangani angka, susunan, logika, organisasi, dan hal lain yang memerlukan pemikiran rasional, berhubungan dengan pertimbangan yang deduktif dan analitis, mereka cenderung menyelesaikan masalah secara terfokus pada satu jawaban yang benar. Pada halaman berikut ini adalah contoh hasil kerja siswa yang memiliki gaya berpikir konvergen dalam menyelesaikan soal matematika.

Dalam hal gaya berpikir, anak yang memiliki gaya berpikir divergen, proses pengembangan kognitif atau berpikir akan berkembang apabila diberi kesempatan untuk mengasahnya dengan memberi kebebasan belajar, berkreasi, berpikir dan memecahkan masalah dari berbagai cara, sebab dengan begitu anak dapat mewujudkan dirinya sebagai seseorang yang memiliki kemampuan untuk melihat bermacam-macam kemungkinan penyelesaian terhadap suatu masalah, memberikan kepuasan kepada siswa dan memungkinkan meningkatkan kualitas hidupnya. Sebaliknya, bagi anak yang memiliki gaya berpikir konvergen, peran guru sebagai pengarah dan fasilitator sangat dibutuhkan untuk mengembangkan pola pikir nya dalam mengerjakan tugas-tugas yang hendak diteliti. Selanjutnya kebiasaan memecahkan masalah dan orientasi perhatian perlu di tumbuh kembangkan termasuk dalam proses belajar di sekolah. Berikut ini adalah contoh hasil kerja siswa yang memiliki gaya berpikir divergen dalam menyelesaikan soal matematika.

Sedangkan pada kelas yang diajarkan dengan strategi pembelajaran ekspositori menunjukkan bahwa hasil belajar siswa yang yang memiliki gaya berpikir konvergen lebih tinggi daripada siswa yang memiliki gaya berpikir divergen, hal ini disebabkan karakteristik siswa yang memiliki gaya berpikir konvergen cenderung menulis manual tentang bagaimana mempelajari materi pelajaran dan mengikuti petunjuk sesuai prosedur, tahap demi tahap, membuat catatan detail, mendengar kuliah (materi pelajaran) sampai ke detaildetailnya yang mengakibatkan siswa yang memiliki gaya berpikir konvergen memperoleh nilai yang lebih tinggi daripada siswa yang memiliki gaya berpikir divergen pada kelas ekspositori.

Temuan penelitian menunjukkan bahwa terdapat interaksi antara strategi pembelajaran dan Gaya Berpikir terhadap hasil belajar matematika. Siswa yang memiliki gaya berpikir divergen memiliki hasil belajar yang lebih tinggi daripada siswa yang memiliki gaya berpikir konvergen yang diajar dengan menggunakan strategi pembelajaran discovery, demikian pula halnya dengan siswa yang memiliki gaya berpikir konvergen memiliki hasil belajar yang lebih tinggi daripada siswa yang memiliki gaya berpikir divergen pada kelas yang diberi strategi pembelajaran ekspositori. Hal ini mengindikasikan adanya interaksi antara penggunaan strategi pembelajaran dengan gaya berpikir terhadap hasil belajar matematika siswa. 
Strategi pembelajaran discovery merupakan strategi pembelajaran yang berpusat pada siswa (student centered) yang menuntut keterampilan mental yang lebih tinggi untuk merancang, melakukan percobaan, mengumpulkan dan menganalisis data yang ada serta pada akhirnya mengambil kesimpulan, dengan demikian siswa belajar melakukan pemecahan masalah secara mandiri dan mengembangkan keterampilan berpikir sehingga melatih keterampilan kognitif siswa untuk menemukan dan memecahkan masalah tanpa pertolongan orang lain. Dalam strategi pembelajaran discovery sangan diharapkan keterlibatan siswa secara aktif agar dapat memecahkan masalah baik secara mandiri maupun secara bersama-sama dalam diskusi secara klasikal dan mampu berpikir bebas.

Pada dasarnya jika dibandingkan secara teoretis dan empirik data yang telah dilakukan bahwa sebenarnya strategi pembelajaran discovery lebih unggul dibelajarkan tanpa mengabaikan karakteristik siswa. Seperti yang diungkapkan oleh Suherman, dkk (2001: 179) sebagai berikut: (1) siswa aktif dalam kegiatan belajar, sebab ia berpikir dan menggunakan kemampuan untuk menemukan hasil akhir; (2) siswa memahami benar bahan pelajaran, sebab mengalami sendiri proses menemukannya. Sesuatu yang diperoleh dengan cara ini lebih lama diingat; (3) menemukan sendiri menimbulkan rasa puas. Kepuasan batin ini mendorong ingin melakukan penemuan lagi sehingga minat belajarnya meningkat; (4) siswa yang memperoleh pengetahuan dengan metode penemuan akan lebih mampu mentransfer pengetahuannya keberbagai konteks; (5) metode ini melatih siswa untuk lebih banyak belajar sendiri.

Bahwa siswa yang memiliki gaya berpikir konvergen akan mendapat hasil belajar yang lebih baik jika diajarkan dengan discovery dari pada diajarkan dengan ekspositori. Namun pada kombinasi uji Scheffe diatas tetap lebih baik siswa yang memiliki gaya berpikir divergen yang diajar dengan discovery daripada siswa yang memiliki gaya berpikir konvergen namun diajar dengan ekspositori. Hal ini sesuai dengan teori yang dikemukakan oleh Roestiyah (2001) bahwa strategi discovery adalah metode mengajar yang mempergunakan teknik penemuan.

Karakteristik siswa gaya berpikir siswa juga menjadi faktor internal yang dapat memacu hasil belajar siswa seperti teori yang dinyatakan Munandar (1992) menjelaskan bahwa gaya berpikir divergen adalah gaya berpikir kreatif, yang merupakan kemampuan berpikir untuk memberikan berbagai kemungkinan jawaban berdasarkan informasi atau data yang diberikan dengan penekanan pada kuantitas, ketepatgunaan, dan beragam jawaban yang lebih bebas dan terbuka.

\section{PENUTUP}

1. Terdapat perbedaan rata-rata hasil belajar matematika antara siswa yang dibelajarkan dengan strategi pembelajara Discovery dengan siswa yang dibelajarkan dengan strategi pembelajaran ekspositori. Rata- rata hasil belajar Matematika siswa yang dibelajarkan dengan menggunakan Strategi Discovery lebih tinggi dari hasil belajar Matematika siswa yang dibelajarkan dengan menggunakan Strategi Ekspositori.

2. Rata-rata Hasil belajar Matematika siswa yang memiliki Gaya Berpikir Divergen lebih tinggi daripada hasil belajar Matematika siswa yang memiliki Gaya Berpikir Konvergen. Rata-rata hasil belajar matematika siswa dengan gaya berpikir divergen baik secara keseluruhan yang dibelajarkan dengan strategi pembelajaran discovery

3. Terdapat interaksi antara penggunaan Strategi Pembelajaran dan Gaya Berpikir dalam mempengaruhi hasil belajar Matematika siswa. Pengaruh tersebut adalah (1) hasil belajar matematika siswa yang dibelajarkan dengan strategi pembelajaran discovery berdasarkan gaya berpikir divergen lebih tinggi dibandingkan dengan hasil belajar matematika siswa yang diajarkan dengan strategi pembelajaran ekspositori berdasarkan gaya berpikir divergen, (2) hasil belajar matematika siswa yang dibelajarkan dengan strategi pembelajaran discovery berdasarkan gaya berpikir divergen lebih tinggi dibanding dengan hasil belajar matematika siswa dengan strategi pembelajaran discovery berdasarkan gaya berpikir konvergen, (3) hasil belajar matematika siswa yang dibelajarkan dengan strategi pembelajaran discovery berdasarkan gaya berpikir divergen lebih tinggi dibandingkan dengan hasil belajar matematika siswa yang dibelajarkan strategi pembelajaran ekspositori dan gaya berpikir konvergen, (4) hasil belajar matematika siswa yang 
dibelajarkan dengan strategi pembelajaran ekspositori berdasarkan gaya berpikir divergen lebih rendah dibandingkan dengan hasil belajar matematika siswa yang dibelajarkan dengan strategi pembelajaran discovery berdasarkan gaya berpikir konvergen. (5) hasil belajar matematika siswa yang dibelajarkan dengan strategi pembelajaran ekspositori berdasarkan gaya berpikir divergen lebih rendah dibandingkan dengan hasil belajar matematika siswa yang dibelajarkan dengan strategi pembelajaran ekspositori berdasarkan gaya berpikir konvergen. (6) hasil belajar matematika siswa dengan strategi pembelajaran ekspositori berdasarkan gaya berpikir konvergen lebih tinggi dibandingkan dengan hasil belajar matematika siswa dengan strategi pembelajaran discovery berdasarkan gaya berpikir konvergen.

\section{DAFTAR PUSTAKA}

Asrori, M. (2010). Psikologi Remaja : Perkembangan Peserta Didik. Jakarta: Bumi Aksara.

Asrori, Mohammad.(2007). Psikologi Pembelajaran. Bandung: Wacana Prima.

Arikunto,S. (2009). Dasar- Dasar Evaluasi Pendidikan (Edisi Revisi). Jakarta: Rineka Cipta

Arikunto,S. (2010). Manajemen Penelitian. Jakarta : Rineka Cipta

Bruner,J.S. (1966). Toward A Theory of Instructional. New York: Norton

Dimyati dan Mujiono.(2000). Belajar dan Pembelajaran. Jakarta: Rineka Cipta.

Depenas. (2004). Materi Pelatihan Terintegrasi. Matematika. Jakarta:
Bagian Proyek Pengembangan Sistem dan Pengendalian Program

Gagnẻ, Robert M and Briggs, Leslie J ( 1979). Principles of Instructional Design. Second Edition. New York: Holt, Rinehart and Winston.

Hamalik, O. (1993), Perencanaan Pengajaran Berdasarkan pendekatan Sistem, Jakarta: Bumi Aksara.

Hamid,K,A. (2009). Teori Belajar dan Pembelajaran. Medan: Unimed

Munandar,Utami.(2009). Pengembangan Kreativitas Anak Berbakat. Jakarta: Rineka Cipta.

Ratumanan, T.G. (2004). Belajar dan Pembelajar. Surabaya: UNESA University.

Roestiyah.(2001). Strategi Belajar Mengajar. Jakarta : Rineka Cipta.

Sanjaya W.(2008). Strategi Pembelajaran berorientasi Standar Proses Pendidikan. Jakarta: Prenada Media Group.

Santrock, J.W. (2010), Psikologi Pendidikan, Jakarta: Kencana Prenada Media Group.

Sihombing, T.(2009). Pengaruh Strategi Pembelajaran Dan Gaya Berpikir Terhadap Hasil Belajar Fisika ( Suatu studi Eksperimen Di SMA Swasta Hang Tuah Belawan) Medan. Tesis tidak diterbitkan. Medan. PPS Unimed

Sloane, Paul (2011). How to be a Brilliant Thinker. Alih bahasa Riga D. Ponziani: Jakarta: Gramedia

Trianto. (2009). Mendesain Model Pembelajaran Inovatif - Progresif. Jakarta: Kencana

Winkel,S.(2009). Psikologi Pengajaran. Yogyakarta: Media Abadi. 